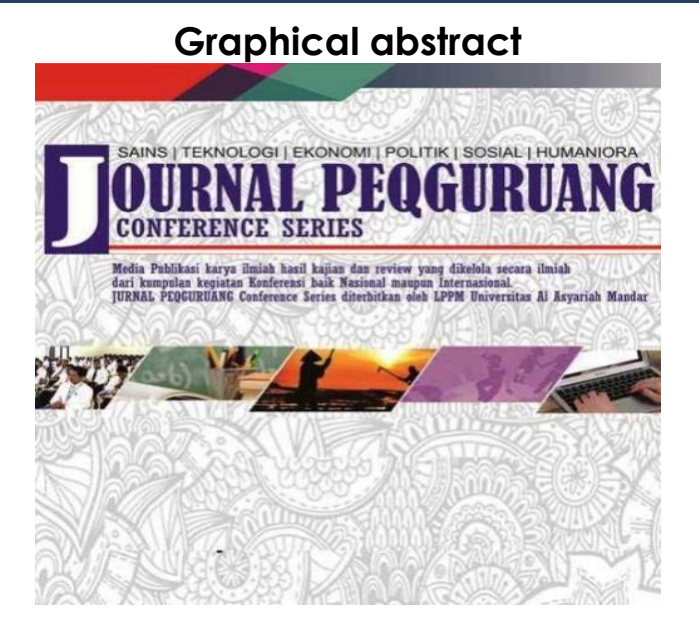

\title{
ANALISIS NOVEL TENTANG KAMU KARYA TERE LIYE MENGGUNAKAN TEORI STRUKTURALIS (UNSUR INTRINSIK)
}

\author{
${ }^{1 *}$ Nuryanti, ${ }^{*}$ Chuduriah Sahabuddin, ${ }^{1 *}$ Abdul Muttalib. \\ *Universitas Al Asyariah Mandar \\ nuryantib@gmil.com
}

\begin{abstract}
This study aims to describe the intrinsic elements that exist in the novel Tentang Kamu by Tere Liye. This research method is descriptive qualitative. The data of this study are structuralist theories. The data source of this research is a novel Tentang Kamu by Tere Liye. Data collection techniques, reading and note taking techniques. The data collected is then described based on structuralist theory (intrinsic element). The steps taken are selecting research objects, reading, identifying, collecting data, comparing, categorizing, and inference. Based on the results of the study, researchers obtained results in the novel Tentang Kamu by Tere Liya containing intrinsic elements including: The theme is the determination of a woman. The grooves used are mixed grooves. The characterization is divided into 5 namely the main character there is 1 figure and there are 8 additional characters, the protagonist is 5 characters and the antagonist characters are 3 figures, simple figures are 8 characters and round figures are 3 figures, static characters are 9 figures and there are developing characters 3 figures, as well as typical figures there are 3 figures. The setting is united between the setting of time, place and atmosphere. The point of view used by the third person perspective "he" is omniscient. And the message is that if we do something seriously, all will not be in vain, both from the trials given in the form of violence, failure and patience as experienced by the main character.
\end{abstract}

Keywords: Novels, Structuralist Studies, Intrinsic Elements

\begin{abstract}
Abstrak
Penelitian ini bertujuan mendeskripsikan unsur intrinsik yang ada dalam novel Tentang kamu karya Tere Liye. Metode penelitian ini adalah deskriptif kualitatif. Data penelitian ini adalah teori strukturalis. Sumber data penelitian ini adalah novel tentang kamu karya Tere Liye. Teknik pengumpulan data, teknik baca dan catat. Data yang terkumpul kemudian dideskripsikan berdasarkan teori strukturalis (unsur intrinsik). Langkah-langkah yang dilakukan yaitu memilih objek penelitian, membaca, mengidentifikasi, mengumpulkan data, membandingkan, kategorisasi, dan inferensi. Berdasarkan hasil penelitian, peneliti memperoleh hasil yakni dalam novel Tentang Kamu karya Tere Liya mengandung unsur intrinsik meliputi: Tema yaitu keteguhan seorang perempuan. Alur yang digunakan alur campuran. Penokohan terbagi atas 5 yaitu tokoh utama ada 1 tokoh dan tokoh tambahan ada 8 tokoh,tokoh protagonis ada 5 tokoh dan tokoh antagonis ada 3 tokoh, tokoh sederhana ada 8 tokoh dan tokoh bulat ada 3 tokoh, tokoh statis ada 9 tokoh dan tokoh berkembang ada 3 tokoh, serta tokoh tipikal ada 3 tokoh. Latar disatukan antara latar waktu, tempat dan suasana. Sudut pandang yang digunakan sudut pandang orang ketiga "dia" mahatahu. Serta Amanatnya yaitu jika kita melakukan sesuatu dengan bersungguh-sungguh maka semua tidak akan sia-sia, baik dari cobaan yang diberikan berupa kekerasan, kegagalan dan kesabaran seperti yang dialami tokoh utama.

Kata kunci : Novel, Kajian Strukturalis, Unsur Intrinsik
\end{abstract}

Article history
DOI: http://dx.doi.org/10.35329/jp.v2i2.939
Received : 12 Agustus 2020 | Received in

Received : 12 Agustus 2020 | Received in revised form : 5 September2020 | Accepted : 15 oktober 2020 


\section{PENDAHULUAN}

Karya sastra lahir dari ungkapan perasaan, pemikiran, ide-ide, kepercayaan seseorang yang dikeluarkan ke dalam bentuk bahasa lisan atau tulisan. Untuk memahami maknanya, karya sastra hanya dapat dikaji berdasarkan unsur intrinsiknya sendiri. Didalam karya sastra terdapat berbagai hal yang dapat dikaji, baik itu dari tokoh yang ada dalam cerita maupun latar cerita berupa latar waktu, tempat ataupun latar sosial.

Membaca adalah melihat serta memahami isi dari apa yang tertulis (KBBI, 2008: 83). Membaca merupakan sebuah kegiatan yang efektif dalam menambah pengetahuan seseorang. Namun tak semua orang memiliki minat membaca apa lagi minat membaca buku. Terkadang orang yang memiliki minat membaca buku adalah orang yang sudah dari usia anak-anak mendapatkan literasi yang baik soal membaca buku sedangkan yang lainnya adalah orang yang memiliki kesadaran akan pentingnya pengetahuan sehingga memotivasi dirinya untuk membaca buku.

Kecenderungan yang membuat seseorang malas membaca juga dipengaruhi oleh buku bacaan yang kurang sesuai dengan minatnya atau buku bacaannya banyak menggunakan bahasa yang tidak dimengerti maksudnya pemilihan katanya menggunakan kata-kata yang jarang dibaca sebelumnya. Maka untuk membangun minat baca dalam diri maka kita sebaiknya memilih buku bacaan yang mudah untuk dipahami Seperti Novel misalnya.

Salah satu genre sastra yang banyak diminati oleh masyarakat adalah novel. Novel sebagai karya sastra dijadikan oleh pengarang sebagai media untuk menyampaikan pesan dan gagasan kepada pembaca berdasarkan pikiran, perasaan, dan pengalamannya.

Novel terdapat atas dua unsur yaitu unsur intrinsik dan ekstrinsik, adapun bagian-bagian dalam unsur intinsik yaitu tema, penokohan, latar, alur/plot, gaya bahasa, sudut pandang dan amanat. Menurut Nurgiyantoro (2013:29), tema merupakan dasar cerita atau gagasan umum dalam sebuah cerita. Unsur-unsur instrinsik lain seperti penokohan, latar, alur/plot yang membangun tema tersebut sedangakan unsur ekstrinsik yaitu Latar Belakang Masyarakat, Latar Belakang Masyarakat dan Nilai Dalam Cerita, Memahami secara mendalam sebuah isi novel biasanya perlu menggunakan pengkajian terhadap novel tersebut. Banyak teori dan pendekatan yang dapat menggunakan dalam mengkaji atau memahami sebuah novel diantaranya adalah menggunakan teori strukturalis.

Struktur karya sastra dapat diartikan sebagai suatu susunan penegasan dan gambaran semua bahan dan bagian yang menjadi komponennya yang secara bersama membentuk kebulatan yang indah (Abrams dalam Nurgiyantoro, 2013 :57). Dipihak lain struktur karya sastra juga merupakan hubungan antara unsur (intrinsik) yang bersifat timbul balik, saling menentukan, saling mempengaruhi, yang secara bersama membentuk satu kesatuan yang utuh (Nurgiyantoro 2013:57).
Analisis Ini bertujuan mengetahui sesuatu yang terdapat dalam sebuah novel, khususnya novel tentang kamu karya Tere Liye sangat diperlukan adanya analisis. Analisis struktural berupaya memahami pesanpesan dan keabsahan ceritanya, tentunya sangat diperlukan adanya sebuah kajian khusus agar tidak terjadi kesalahpahaman dalam memahaminya, juga menambah ilmu bagi pembaca terkait dengan karya sastra. Dengan alasan inilah mengapa kajian ini dilakukan Novel Tere Liye sebagian besar bahasa yang digunakan cenderung sederhana dan mudah dipahami dibandingkan novel-novel yang lain.

\section{Kesusatraan}

Sastra merupakan sebuah karya tulis yang jika dibandingkan dengan tulisan lain, memiliki berbagai ciri keunggulan seperti keaslian, keartistikan, keindahan dalam isi dan ungkapannya (KBBI 2008).

\section{Genre Sastra}

Karya sastra menurut genre atau jenisnya terbagi atas puisi, prosa dan drama

Novel

Kata novel berasal dari bahasa Italia novella (dalam bahasa Jerman novelle, dan dalam bahasa Inggris novel) yang secara harfiah berarti sebuah barang baru yang kecil. Wiyatmi (2009:28) menjelaskan novel sebagai bagian dari karya sastra berbentuk narasi yang isinya merupakan suatu kisah sejarah atau sebuah deretan peristiwa.

Nurgiyantoro (2013:18) menyatakan, novel merupakan karya yang bersifat realistis dan mengandung nilai psikologi yang mendalam, sehingga novel dapat berkembang dari sejarah, surat-surat, bentukbentuk nonfiksi atau dokumen-dokumen, sedangkan roman atau romansa lebih bersifat puitis. Dari penjelasan tersebut dapat diketahui bahwa novel dan romansa berada dalam kedudukan yang berbeda. Jassin (dalam Nurgiyantoro, 2013:18) membatasi novel sebagai suatu cerita yang bermain dalam dunia manusia dan benda yang di sekitar kita, tidak mendalam, lebih banyak melukiskan satu saat dari kehidupan seseorang dan lebih mengenai suatu episode.

\section{Teori Struktural}

Struktur karya sastra dapat diartikan sebagai suatu susunan, penegasan dan gambaran semua bahan dan bagian yang menjadi komponennya yang secara bersama membentuk kebulatan yang indah (Abrams dalam Nurgiyantoro , 2013 :57). Dipihak lain struktur karya sastra juga merupakan hubungan antara unsur (intrinsik) yang bersifat timbul balik, saling menentukan, saling mempengaruhi, yang secara bersamaan membentuk satu kesatuan yang utuh (nurgiyantoro 2013:57). 


\section{Unsur Unsur Kajian}

Kajian struktural meliputi kajian mengenai unsur-unsur pembangun karya sastra atau disebut dengan unsur intrinsik dan pembangun di luar karya sastra atau yang biasa disebut unsur ekstrinsik. Kajian struktural sebuah novel meliputi unsur intrinsik dan ekstrinsik yang terdapat dalam novel. Unsur intrinsik yang dikaji dalam novel meliputi: tema, penokohan, alur, latar, dan sudut pandang.

\section{Tema}

Tema adalah gagasan, ide dan pikiran utama. Staton dkk (Nurgiyantoro, 2013:114) mengemukakan bahwa tema (theme) adalah makna yang dikandung oleh sebuah cerita

\section{Penokohan}

Penokohan yaitu penciptaan citra tokoh dalam cerita. Adapun Nurgiyantoro (2013:258-278), membedakan tokoh menjadi lima yaitu, tokoh utama dan tokoh tambahan, tokoh protagonis dan tokoh antagonis, tokoh sederhana dan tokoh bulat, tokoh statis dan tokoh berkembang, tokoh tropikal dan tokoh netral

\section{Alur Atau Plot}

Alur atau plot adalah rangkaian peristiwa yang menggerakan cerita mencapai efek tertentu dan sekaligus membangkitkan suspense dan surprise pada pembaca. Alur sebagai urutan peristiwa dalam sebuah cerita memiliki tahapan sebagai berikut (Zulfarida, 2019:21).
a. Tahap pengenalan Orientasi
b. Tahap pemunculan konflik
c. Tahap klimaks
d. Tahap antiklimaks
e. Tahap penyelesaian atau Resolusi

\section{Latar Atau Setting}

Latar (setting) yaitu segala keterangan mengenai waktu, ruang dan suasana dalam suatu cerita.

\section{Sudut Pandang}

Sudut pandang dalam karya sastra mempersoalkan siapa yang menceritakan atau dari posisi dan tindakan dilihat.

\section{Amanat}

Siswandarti (dalam, Zahra 2017 :19) mengantakan bahwa amanat adalah "pesan-pesan yang ingin disampaikan pengarang melalui cerita, baik tersurat maupun tersirat".

Sedangkan unsur ekstrinsik yang dikaji meliputi: Latar belakang Pengarang, Latar belakang Masarakat dan Nilia-nilai dalam Novel

\section{Latar belakang Masyarakat}

Dalam menciptakan suatu karya sastra pengarang perlu memperhatikan keadaan masyarakat baik dari segi kebudayaan maupun kehidupan sosial masyarakat-nya sehingga suatu karya sastra yang dihasilakan memberikan kepuasaan kepada pembaca karena memberi informasi tentang tata aturan yang berlaku disebuah daerah

\section{Latar belakang Pengarang}

Latar belakang kehidupan pengarang sebagai dari unsur ekstrinsik sangat mempengaruhi karya sastra

\section{Nilia-nilai dalam Novel}

Adapaun nilai yang terkandung dalam cerita yang dimaksud adalah sebagai berikut:

a. Nilai religius

Nilai religius bertujuan untuk mendidik agar manusia lebih baik menurut tuntutan agama dan selalu ingat kepada tuhan

b. Nilai Moral

Nilai moral adalah suatu bagian dari nilai, yaitu nilai yang menangani kelakuan baik atau buruk dari manusia

c. Nilai sosial

Nilai sosial merupakan hikmah yang dapat diambil dari perilaku soial dan tata cara hidup sosial.

d. Nilai Budaya

Nilai-nilai budaya menurut Rosyadi (1995:74) merupakan suatu yang dianggap baik dan berharga oleh suatu kelompok masyarakat atau suku bangsa yang belum tentu dipandang baik pula oleh kelompok masyarakat atau suku bangsa lain sebab nilai membatasi dan memberikan karakteristik pada suatu masyarakat dan kebudayaannya

\section{METODE PENELITIAN}

\section{Jenis Penelitian}

Jenis penelitian ini adalah deskriptif kualitatif dengan metode content analysis atau analisis isi. Penelitian ini mendeskripsikan atau menggambarkan apa yang menjadi masalah, kemudian menganalisis dan menafsirkan data yang ada.Metode content analysis atau analisis isi yang digunakan untuk menelaah isi dari suatu dokumen, dalam penelitian ini dokumen yang dimaksud adalah novel tentang kamu karya tere liya.

\section{Waktu dan Lokasi Penelitian}

1. Tempat Penelitian

Tempat penelitian ini di lakukan di Perpustakaan Universitas Al Asyariah Mandar.

2. Waktu Penelitian penelitian dilakukan bulan april hingga mei 2020

\section{Desain Penelitian}

peneliti menggunakan desain penelitian yang sifatnya deskriptif kualitatif. . Maksud dari deskriptif kualitatif ialah memberikan gambaran, pemaparan , atau penjelasan berlandasan pada hasil analisis terhadap novel tentang kamu karya tere liye 


\section{Sumber Data dan Data}

Sumber data adalah Subjek yang menjadi masalah atau tempat data itu di peroleh (Arikunto, 1992: 20). Penelitian ini menyangkut tentang analisi novel tentang kamu karya Tere Liye menggunakan teori strukturalis, sehingga yang menjadi sumber data adalah novel Tentang Kamu karya Tere Liye, sedangkan data yang disaring adalah teori strukturalisnya yang terdapat dalam novel Tentang kamu karya Tere Liye.

\section{Instrumen Penelitian}

Dalam penelitian ini, peneliti sendiri yang menjadi instrumen yang berperan sebagai perencana, pengumpul data, penafsir data, penganalisis dan pelapor hasil penelitian (menurut Moleong 1994:121 dalam Azis, 2012).

\section{Teknik Pengumpulan Data}

Teknik pegumpulan data yang digunakan dalam penelitian ini adalah teknik baca dan catat.

\section{Teknik Analisis Data}

Teknik analisis data yang digunakan dalam penelitian ini adalah teknik deskriptif kualitatif. Langkah-langkah yang digunakan untuk menganalisis data yaitu :

1. Perbandingan

Data-data yang telah diperoleh dari pembacaan novel yang berulang-ulang dimasukkan ke dalam kartu data

2. Kategorisasi

Data-data yang telah dibandingkan tersebut kemudian dikelompokkan. Pengelompokkan data berupa teori strukturalisnya.

3. Inferensi

Data-data yang telah dikelompokkan berdasarkan kategori, selanjutnya dideskripsikan sesuai dengan interpretasi dan pengetahuan peneliti tentang teori struktural

\section{HASIL PENELITIAN DAN PEMBAHASAN}

\section{Tema}

Novel Tentang Kamu karya Tere Liye bertemakan keteguhan seorang perempuan (Sri Ningsih). Di awali dari bagaimana Sri Ningsih begitu sabar menghadapi ibu tirinya, bagaimana iya menyikapi permasalahan di madrasah, ketabahannya dalam membangun bisnis di Jakarta yang jatuh bangun, lalu sabarnya ia menerima takdir bahwa ia melahirkan anak-anaknya yang tak lama setelah dilahirkan langsung meninggal serta kematian suaminya, dan begitu kuatnya ia menerima teror dari sahabatnya sendiri sehingga ia selalu kabur ketika ia di dapati. Semua lika-liku hidup yang dilaluinya ia memilih untuk terus sabar dan menerima semuanya tanpa banyak mengeluh.

Kutipan di Bawah ini mewakili salah satu tema dari Novel Tentang Kamu:
"Sri akan bertahan. Tidak ada yang bisa mengalahkan kekuatan dan kesabaran hati seorang sri ningsi. Jika kita bisa menyaksikannya, dari tubunya sekarang menguar cahaya kesabaran yang indah. Jangan cemas, sri akan sembuh" (TK,2016:126)

Kutipan diatas dapat ditentukan sebagai contoh bagaimana keteguhan seorang sri ningsi dalam menerima siksaan dari ibu tirinya tanpa pernah mengeluh atau membalas perlakuan ibu tirinya, padahal dia bisa saja karena tubuhnya sudah setinggi ibu tirinya dan umurnya juga sudah 14 tahun tapi sayangnya dia tetap memilih untuk menerimanya.

Alur

Secara garis besar alur dalam novel Tentang Kamu karya Tere Liye menggunakan alur campuran atau maju mundur karna novel ini pada tahap awal menceritakan Zaman akan menangani kasus harta warisan yang ditinggalkan Sri Ningsih, setelah itu dalam penanganan kasus itu banyak kisah yng diceritkan mengenai masa lalu Sri Ningsih lalu kembali ke masa Sekarang.

Adapun tahapan Alur dalam novel Tentang Kamu adalah sebagai berikut:

a. Tahap pengenalan Orientasi (Tahap Awal)

Salah satu kutipan pada tahap pengenalan orientasi (tahap awal)

"Klien ini mewariskan aset berbentuk kepemilikan saham senilai satu miliar poundsterling. Dalam mata uang asal negaramu, itu setara19 triliun rupiah, bukan? Dengan warisan sebesar itu, dia lebih kaya dibanding Ratu Inggris dan keluarganya. Namanya bisa masuk dalam 100 orang terkaya di kerajaan inggris" Sir Thompson menghela nafas, "Tapi selain nilai warisan yang luar biasa besar itu, kita punya masalah serius, karna ini jenis penyelesaian harta warisan yang amat pelik sekaligus menarik" ".

(TK, 2016:11)

Kutipan di atas menggambarkan tahap pengenalan karena menceritakan awal dari pengenalan tokoh utama dan permasalahan yang dihadapi yaitu memiliki harta yang terbilang sangat banyak tanpa diketahui ahli warisnya.

b. Tahap Pemunculan Konflik

Salah satu kutipan pada tahap pemunculan konflik

"Nyala api cemburu itu juga telah menyala di hati Mbak Lastri. Semua orang tahu, jika besok lusa Musoh jadi menggantikan Kiai Ma'sum, maka secara otomatis Mbak Lastri akan menjadi Nyai Kiai, mengurus seluruh asrama putri. Tapi dengan Arifin terus menanjak posisinya, impian menjadi Nyai Kiai itu kosong belaka Mbak Lastri mulai membenci Nur'aini”. (TK, 2016 : 177)

Kutipan diatas bisa dikatakan sebagai tahap pemunculan konflik karena pada tahap ini adanya benci yang mendalam sehingga terjadinya tragedi dimadrasah dan menjadi awal kebencian pemeran lastri terhadap sahabatnya sri ningsi selaku pemeran utama dalam 
cerita dan menjadi bagian awal konflik dari kehidupan sri ningsi.

\section{c. Tahap klimaks}

Salah satu kutipan pada tahap klimaks

"Nur, aku baru saja mengalami mimpi buruk. Masa Lalu itu nyata. Benar-benar kembali. Aku tidak tau apa yang harus kulakukan. Saat menulis surat ini tubuhku gemetar ketakutan.

Maafkan aku, Nur aku harus pergi.

Aku sungguh-sungguh berterima kasih memiliki sahabat terbaik sepertimu Nur. Sri Ningsih" (TK,2016 : 271)

Kutipan diatas adalah tahap klimaks karena disinilah sri ningsi merasa harus meninggalkan semua kenangan dimasa lalunya yang kembali menghantuinya dengan meninggalkan semua yang berhubungan dengan masa lalu dan kehidupannya di jakarta dengan pergi ke london.

\section{d. Tahap Antiklimaks}

Salah satu kutipan pada tahap antiklimaks

"Zaman menahan nafas, tangannya gemetar mengambil surat itu.

Inilah benda yang dia cari-cari selama ini.

Surat wasiat Sri Ningsih" (TK, 2016:486)

Kutipan diatas termasuk dalam tahap antiklimaks karena dapat kita tentukan dari tokoh zaman selaku pengacara yang menangani kasus sri ningsi yang mulai mengetahui adanya surat wasiat yang telah dicarinya selama bebrapa hari. Surat Wasiat ini juga sebagai senjata utama untuk melawan Lastri dalam pengadilan.

e. Tahap penyelesaian atau Resolusi

Salah satu kutipan pada tahap penyelesaian atau resolusi

"Jika fisiknya sudah pulih, aku akan membawanya ke Surakarta. Nur'aini sudah kuhubungi, dia berjanji akan merawat Tilamuta di sana hingga sembuh. Aku juga akan meminta Ode ke Surakarta. Tilamuta bisa bertemu dengan orang-orang yang pernah mengenal dan selalu menyayanginya, termasuk teman-temannya dulu di madrasah. Keluarga Rajendra Khan juga sedang dalam perjalanan menuju kesini, mereka hendak menziarahi makam Sri Ningsih esok pagi-pagi”. (TK, $2016: 517)$

Kutipan diatas adalah Tahap penyelesaian atau Resolusi karena dimana tokoh zaman yang selaku pengacara kasus sri ningsi dapat menyelesaikan semuanya dan menemukan kembali adik sri ningsi yang disangka selama ini telah meninggal, yang ternyata disekap oleh lastri sehinggah menyebabkan trauma mendalam pada tilamuta adik tiri sri ningsi.

\section{Penokohan}

Dalam novel Tentang Kamu karya Tere Liye, tokoh-tokoh mulai bermunculan sesuai dengan jalan ceritanya, satu persatu mulai ditampakkan pengarang, setiap alur cerita yang dikisahkan maka tokoh-tokoh baru akan muncul di dalamnya
Tabel: 4.7 Unsur Intrinsik(Penokohan)

\begin{tabular}{|l|l|l|}
\hline NO & Analisis Penokohan & $\begin{array}{l}\text { Jumlah data Tokoh yang } \\
\text { ditemukan }\end{array}$ \\
\hline 1 & a.Tokoh Utama & 1 tokoh \\
& b.Tokoh Tambahan & 8 tokoh \\
\hline 2 & a.Tokoh protagonis & 5 tokoh \\
& b.Tokoh antagonis & 3 tokoh \\
\hline 3 & a.Tokoh sederhana & 8 tokoh \\
& b.Tokoh bulat & 3 tokoh \\
\hline 4 & a.Tokoh statis & 9 tokoh \\
& b.Tokoh berkembang & 3 tokoh \\
\hline 5 & Tokoh tipikal & 3 tokoh \\
\hline
\end{tabular}

\section{Sudut Pandang}

Dalam novel Tentang Kamu Karya Tere Liye sudut pandang yang digunakan adalah sudut pandang orang ketiga yaitu jenis "Dia" Mahatahu jenis sudut pandang ini narator dapat menceritakan apa saja hal-hal yang menyangkut tokoh "dia" tersebut. ia mengetahui berbagai hal tentang tokoh, peristiwa, dan tindakan termasuk motivasi yang melatar belakanginya:

Berikut adalah salah satu kutipan yang berkaitan dengan sudut pandang persona ketiga jenis "dia" Mahatahu:

"Zaman-nama Lengkapnya Zaman Zulkarnaen dan dia bukan turis-baru saja keluar dari stasium kereta bawah tanah victoria, zaman merapatkan mantel tebalnya, angin kencang yang menerbangkan dedaunan yang kering membuat anak usia 30 tahun yang berasal dari negara tropis itu menggigil. Dia tidak pernah terbiasa dengan iklim London, walaaupun sudah menetap sejak menyelesaikan kuliah master hukum di oxford university" (TK, $2016: 01)$

Kutipan diatas menunjukkan sudut padang orang ketiga jenis "dia" mahatahu karena pengarang menjelaskan dan mengenalkan tokoh zaman zulkarnaen begitu detail. Mulai dari umur sampai tidak biasanya Zaman pada iklim London.

\section{Amanat}

Dalam novel Tentang Kamu karya Tere Liye amanat tersampaikan melalui tokoh-tokoh di dalamnya terutama Sri Ningsih secara tidak langsung menyampaikan amanat kepada pembacanya. Berdasarkan dari tema yang ada dalam novel ini yaitu keteguhan seorang perempuan. Pengarang menyampaikan amanat kepada pembacanya, berikut amanat yang dapat diambil dalam novel ini :

"memang bukan. Tapi tempat ini telah memberiku pengalaman menarik dua jam tekahir,membuatku belajar banyak hal baru. Selain bagiku janji adalah janji, setiap janji sederhana apapun itu, memiliki kehormatan. Besok lusa aku akan kembali menemuinya, walaupun boleh jadi miximillien sudah tidak mengingatku. Aku sunggu-sunggu mengatakan kalimat tadi. Itu bukan excuse.” (TK,2016:45)

Kutipan diatas dapat kita simpulkan bahwa "setiap janji sederhana apapun itu, memiliki kehormatan" maksud dari kutipat tersebut adalah 
sesederahana apapun janji kepada seseorang harus ditepati meski mungkin terlihat tidak penting tapi saat kita telah berjanji maka alasan apa pun itu kita harus menepatiny.

\section{Simpulan}

Berdasarkan analisis yang telah dilakukan terhadap Novel Tentang Kamu karya Tere Liye maka disimpulkan bahwa unsur intrinsik meliputi : Tema yaitu keteguhan seorang perempuan. Alur yang digunakan alur campuran. Penokohan terbagi atas 5 yaitu tokoh utama ada 1 tokoh dan tokoh tambahan ada 8 tokoh,tokoh protagonis ada 5 tokoh dan tokoh antagonis ada 3 tokoh, tokoh sederhana ada 8 tokoh dan tokoh bulat ada 3 tokoh, tokoh statis ada 9 tokoh dan tokoh berkembang ada 3 tokoh, serta tokoh tipikal ada 3 tokoh. Latar yang digunakan disatukan antara latar waktu, tempat dan suasana. Sudut pandang yang digunakan sudut pandang orang ketiga "dia" mahatahu. Serta Amanatnya yaitu jika kita melakukan sesuatu dengan bersungguh-sungguh maka semua tidak akan sia-sia, baik dari cobaan yang diberikan berupa kekerasan, kegagalan dan kesabaran seperti yang dialami tokoh utama.

\section{DAFTAR PUSTAKA}

Andriani, Andriani. "Peningkatan Kemampuan Menganalisis Unsur Intrinsik Cerpen Dengan Model Inside Outside Circle Siswa Kelas XI Ipa2 SMA Negeri 1 Polewali Kabupaten Polewali Mandar." Pepatudzu: Media Pendidikan dan Sosial Kemasyarakatan 11.1 (2016): 19-32.

Ahmadi, 2016. Analisis Struktural Cerita Rakyat Mandar dalam Buku Kumpulan Cerita Hasil Sayembara Penulisan Cerita Rakyat Mandar Oleh Opy. MR. Polewali Mandar. Universitas Al Asyariah Mandar.

Azis, Anwar. 2012.Analisis Nilai-Nilai pendidikan Dalam Novel Negri 5 Menara Karya A. Fuadi. Skripsi. (tidak diterbitkan)

Depertemen Pendidikan Nasional.2008. Kamus Besar Bahasa Indonesia.Jakarta: Balai Pustaka. Mulyadi, Seto,dkk.2019.Metode Penelitian Kualitatif Dan Mixed Method.Depok : PT Rajagrafindo Persada.

Muthmainnah, Muthmainnah, Naim Irmayani, and Nurmiati Nurmiati. "Meningkatkan Kemampuan Menganalisis Unsur Intrinsik Teks Drama melalui Metode Struktural Kelas VIII B SMP Negeri 2 Tinambung." Journal Peqguruang: Conference Series. Vol. 1. No. 2. 2019.
Nurgiyantoro, Burhan.2013. Teori Pengkajian Fiksi.Yogyakarta : Gadjah Mada University Press

Tere Liye.2016.Tentang Kamu. Jakarta: Republika.

Wiyatmi.2009.Pengantar Kajian Sasta.Yogyakarta: Pustaka Book Publisher.

Zahfarina, dewi. 2018. Analisis Struktural Novel Tsumuji Dabura Karya Miyashita Natsu dan Shouji Yukiya Suatu Tinjauan Struktural cerita rekaan. Semarang. Universitas Deponogoro Semarang

Zahra, Nur Oktavian Amri. 2017. Tema Dan Amanat Dalam Novel "Memang Jodoh" Karya Marah Rusli Serta Manfaatnya Sebagai Alternatif Materi Pembelajaran Apresiasi Sastra Di Sma. Jember: Fkip Universitas Jember

Zulfarida, Dewi Asiyah. 2019. Analisis Struktural dan Nilai- Nilai Pendidikan Karakter pada Novel Assalamualaikum Calon Imam karya Madaniah. Surakarta. Fakultas Adab dan Bahasa Institut Agama Islam Negeri Surakarta

Adriani, A. Y., Muttalib, A., \& Irmayani, N. (2020). Analisis Film Perempuan Berkalung Sorban Karya Hanung Bramantyo melalui Model Sara Mills. Pepatudzu: Media Pendidikan dan Sosial Kemasyarakatan, 16(1), 61-71. 